\title{
Combustion Characteristics of Animal Manures
}

\author{
Pravin Kumar Sahu, Suryakant Chakradhari, Satendra Dewangan, \\ Khageshwar Singh Patel* \\ School of Studies in Environmental Science, Pt. Ravishankar Shukla University, Raipur, India \\ Email: patelks_55@hotmail.com
}

Received 26 February 2016; accepted 21 May 2016; published 24 May 2016

Copyright (C) 2016 by authors and Scientific Research Publishing Inc.

This work is licensed under the Creative Commons Attribution International License (CC BY). http://creativecommons.org/licenses/by/4.0/

c) (i) Open Access

\begin{abstract}
A huge amount of waste from the cattle livestock and bird poultry are generated using as manure and solid fuel. In this work, the heat value and proximate parameters of livestock and poultry manures are described. The calorific value of manures $(n=22)$ was ranged from $2580-11,200$ $\mathrm{kcal} / \mathrm{kg}$ with mean value $(\mathrm{p}=0.05)$ of $5333 \pm 1073 \mathrm{kcal} / \mathrm{kg}$. The effect of cattle age and additives i.e. $\mathrm{NaNO}_{3}$ and $\mathrm{Na}_{2} \mathrm{WO}_{4}$ in the heat value of the manures are discussed. The chemical characteristics of the emitted particulate matters (PM) and ash residues are highlighted.
\end{abstract}

\section{Keywords}

Livestock, Manure, Poultry, Heat Value, Particulate Matters

\section{Introduction}

The enormous increase in the quantum and diversity of waste materials generated by animals and their potentially harmful effects on the environment and public health, have led to an increasing awareness about an urgent need to adopt scientific methods for safe disposal of wastes. In order to minimize the generation of wastes and to reuse and recycle them, the technologies for recovery of energy from wastes play a vital role in mitigating the problems. There are a wide range of animal wastes that can be used as sources of the energy. The most common sources are animal and poultry manures. The increasing demand for energy and the high cost of fossil fuels have led to increased interest in such renewable energy sources as animal manure. The animal waste is subjected to different thermo chemical conversion processes such as direct combustion, gasification, pyrolysis, etc. The calorific value (CV) of animal manures was reported by many researchers [1]-[10]. In this study, CV and proximate analytical data (i.e. moisture, volatile matters and ash content) of manures derived from 22 species are described. The compari-

${ }^{*}$ Corresponding author. 
son of combustion properties of the most commonly available cattle manure with biomass and coal is made.

\section{Materials and Methods}

\subsection{Sample Collection}

The first morning stool of 22 animals and birds of Raipur city and Nandanvan Garden was collected manually in December, 2015. Similarly, the rice straw was collected after harvesting in December, 2015. The coal sample was collected from Korba coal mines in December, 2015. They were stored in 1000-mL cleaned glass bottles with subsequent drying at $50^{\circ} \mathrm{C}$ for 2 days in an (RS) oven. The sample was crushed and the particles of $<0.25 \mathrm{~mm}$ was sieved out.

\subsection{Determination of Bulk Density, Moisture, Calorific Value and Ash Residue}

The density of the biomass affects significantly the heat value. The bulk density (BD) was measured by the water replacement method [11]. $25 \mathrm{~mL}$ pure water will be taken into a $50-\mathrm{mL}$ graduated cylinder. A $5.0 \mathrm{~g}$ of the sample was poured in the cylinder by noting the volume enhancement. The mass of the displaced water was calculated by multiply with water density at the particular working temperature.

The moisture content of the A samples were analyzed by heating it at $105^{\circ} \mathrm{C} \pm 2^{\circ} \mathrm{C}$ till constant weight is observed. The ash content of the materials was determined by heating the sample at $600^{\circ} \mathrm{C}$ for $6 \mathrm{hr}$ [12]. The calorific value was determined experimentally using a Digital Microprocessor Based Bomb Calorimeter UTS 1.34, Advance Research Instruments Co., New Delhi as described in the literature [13]. A $1.0 \mathrm{~g}$ of manure sample was weighed and placed in the stainless steel combustion capsule. The combustion capsule containing the sample was then lowered in the wire bomb head while the bomb head was on its support. A $10 \mathrm{~cm}$ long fuse wire was firmly fixed to the electrodes to facilitate complete combustion. Then $1 \mathrm{~mL}$ of water was added to the bomb cylinder and the sealing ring of the bomb head was moistened. The bomb was carefully lowered into the cylinder and tightly closed with the sealing ring. The oxygen gas was flowed into the combustion cylinder. The bomb cylinder was then lowered into the calorimeter bucket. The calorimeter cover was carefully placed and the thermometer bucket lowered. The power was then switched on to start the auto temperature adjustment and the stirring motor. The initial temperature was recorded after equilibrium was attained i.e. after $5 \mathrm{~min}$. The bomb content was then fired using the ignition switch. The bucket temperature i.e. final temperature was recorded after it had stabilized i.e. after $5 \mathrm{~min}$. The difference between the original length and the new length was multiplied by 0.335 to obtain the number of calories liberated by combustion of the fuse (fuse wire correction). For every sample, calorific value in $\mathrm{kcal} / \mathrm{kg}$ was calculated using the following equation:

$$
G C V=\left[\left\{W_{e} \cdot \Delta T\right\}-\left\{W_{1}(4.18)+W_{2}(0.335)\right\}\right] / M
$$

where, $G C V, M, W_{e}, W_{1}, W_{2}$ and $\Delta T$ represent gross calorific value of species (kcal $/ \mathrm{kg}$ ), weight of sample, water equivalent, weight of cotton thread, weight of fuse wire and rise in temperature, respectively.

The content of volatile compounds including moisture was analyzed by using a Metller Thermogravimetric Analyzer-TGA-2 at heating rate of $20^{\circ} \mathrm{C} / \mathrm{min}$.

The IBM SPSS Statistics 23 was used for the statistical and cluster analysis in the present work [14].

\subsection{Emission Fluxes of Particulate Matters}

The flux of $\mathrm{PM}_{10}$ was determined by burning the materials in a closed chamber $\left(0.5 \times 0.5 \times 0.5 \mathrm{~m}^{3}\right)$ equipped with the exhaust fan and UC Davis (USA) portable air sampler in December, 2015. The $\mathrm{PM}_{10}$ emitted in a closed chamber was collected over the weighted $47-\mathrm{mm}$ quartz filter. The $\mathrm{PM}_{10}$ mass was weighted out, and the flux was evaluated by dividing the $\mathrm{PM}_{10}$ mass with amount of the material burnt.

\subsection{Segregation of Particulate Matters}

The Anderson sampler (1531-107B-G289X) with eight stages: $\mathrm{PM}_{10.0-9.0}, \mathrm{PM}_{9.0-5.8}, \mathrm{PM}_{5.8-4.7}, \mathrm{PM}_{4.7-3.3}, \mathrm{PM}_{3.3-2.1}$, $\mathrm{PM}_{2.1-1.1}, \mathrm{PM}_{1.1-0.7}$ and $\mathrm{PM}_{0.7}$ modes was used for the collection of respirable particulate matters $\left(\mathrm{PM}_{10}\right)$ in the segregation forms. The sampler was run for $2 \mathrm{hr}$ during burning of stool samples in December, 2015. The mass of dried loaded and blank filters were weighted out. 


\subsection{Analysis}

The $\mathrm{pH}$ value of ash extract was determined by the Hanna $\mathrm{pH}$ meter. The Dionex ion chromatography- 1100 was used for monitoring of anions and cations. The content of elemental carbon (EC) and organic carbon (OC) were determined by the thermal method.

The stool or ash extract was prepared by equilibrating $5 \mathrm{~g}$ dried sample with $25 \mathrm{~mL}$ deionized water in $100-\mathrm{mL}$ glass conical flask for $6 \mathrm{hr}$ in the ultrasonic bath. The $\mathrm{pH}$ value of the filtrate was measured with the Hanna $\mathrm{pH}$ meter.

\section{Results and Discussion}

\subsection{Physical Characteristics of Stool}

The physical characteristics of the manures are shown in Table 1. All stool samples were colored with bad smell due to emission of the volatile organic compounds. The $\mathrm{pH}$ value of the stool extracts $(\mathrm{n}=22)$ was ranged from 3.5 - 10.4 with mean value $(\mathrm{p}=0.05)$ of $7.0 \pm 0.8$. Among them, the lowest $\mathrm{pH}$ value of bird i.e. Parrot was observed, may be due to loading with uric acid. The stools of several animals (i.e. Samber, H. Bear, Rabbit, Hen, Parrot, Pigeon, Duck, Cat, White tiger, and Lion) were found to be acidic, Table 1 . The $\mathrm{pH}$ value of the stool extract was partially negatively correlated $(\mathrm{r}=-0.31)$ with the $\mathrm{CV}$, may be due to higher inorganic contents as shown in Figure 1.

\subsection{Bulk Density of Stool}

The bulk density $(\mathrm{BD})$ of stools had fare correlation $(\mathrm{r}=0.56)$ with the $\mathrm{CV}$, may be due to loading of stool with the organic matrix. The BD value $(\mathrm{n}=22)$ was ranged from $570-1800 \mathrm{~kg} / \mathrm{m}^{3}$ with mean value $(\mathrm{p}=0.05)$ of $1009 \pm 120 \mathrm{~kg} / \mathrm{m}^{3}$. The higher BD value for manure of the carnivorous animals was marked, may be due to loading with the inorganic compounds as shown in Table 1 and Figure 1.

\subsection{Moisture Content}

High moisture content (MC) of manure has a much lower net energy density by mass, owing to the weight of the

Table 1. Physical and combustion characteristics of animal stools.

\begin{tabular}{ccccccccc}
\hline S. No. & Animal & Scientific name & Family & Color & $\mathrm{pH}$ & $\mathrm{BD} \mathrm{kg} / \mathrm{m}^{3}$ & $\mathrm{MC} \%$ & $\mathrm{CV} \mathrm{kcal} / \mathrm{kg}$ \\
\hline 1 & Human & Homo sapiens & Hominidae & BI & 5.6 & 570 & 2.5 & 11,200 \\
2 & Cattle & Bostaurus & Bovidase & DG & 9.9 & 700 & 2.8 & 3900 \\
3 & Blue cattle & A. Americana & Bovidase & DG & 10.4 & 800 & 3.2 & 3560 \\
4 & Bull & Bostaurus & Bovidase & DG & 9.4 & 760 & 3.1 & 3790 \\
5 & Buffalo & Synceruscaffer & Bovidase & DG & 9.2 & 740 & 2.9 & 3900 \\
6 & Goat & CA hircus & Bovidase & DG & 9.7 & 960 & 3.5 & 2970 \\
7 & Sheep & Ovisaries & Bovidase & DG & 9.5 & 980 & 3.3 & 3160 \\
8 & Deer & Cervidae & Cervidase & DG & 7.1 & 990 & 2.7 & 4400 \\
9 & B. dear & Muntiacini & Cervidase & DG & 7.3 & 830 & 3.0 & 3260 \\
10 & Samber & Rusa unicolor & Cervidase & DG & 5.5 & 1040 & 2.6 & 4980 \\
11 & Horse & Equuscaballus & Equidae & GBr & 7.1 & 1030 & 3.1 & 3100 \\
12 & H. bear & U. arctosisabellinus & Ursidae & DG & 4.1 & 890 & 2.8 & 3440 \\
13 & Rabbit & O. cuniculus & Leporidae & Black & 4.7 & 780 & 3.5 & 2580 \\
14 & Hen & Gallus gallus & Phasianidae & WBr & 5.7 & 1080 & 2.4 & 5440 \\
15 & Hyena & Hyaenidae & Hyaenidae & Gray & 7.1 & 1800 & 1.3 & 10,700 \\
16 & Parrot & Psittaciformes & Cacatuoidea & WBr & 3.5 & 1070 & 2.1 & 5630 \\
17 & Pigeon & Columbidae & Columbidae & WBr & 5.7 & 1150 & 1.9 & 6200 \\
18 & Duck & Anasplatyrhynchos & Anatidae & WBr & 6.8 & 1050 & 2.0 & 5580 \\
19 & Cat & FelisCatus & Felidae & Gray & 6.8 & 1120 & 2.1 & 5440 \\
20 & Dog & Canis lupus familiaris & Canidae & BI & 6.0 & 1050 & 2.0 & 6900 \\
21 & White tiger & Pantheratigris & Felidae & Gray & 5.9 & 1100 & 1.8 & 6440 \\
22 & Lion & Pantheraleo & Felidae & Gray & 6.5 & 1700 & 1.2 & 10,750 \\
\hline
\end{tabular}

$\mathrm{B}=$ Barking, $\mathrm{H}=$ Himalayan, $\mathrm{A}=$ Antilocapra, $\mathrm{CA}=$ Capra aegagrus, $\mathrm{U}=$ Ursus, $\mathrm{O}=$ Oryctolagus, $\mathrm{GBr}=\mathrm{Greenish}$ brown, $\mathrm{DG}=\mathrm{Dark}$ green, $\mathrm{WBr}=$ White brown, $\mathrm{BI}=$ Blackish. 

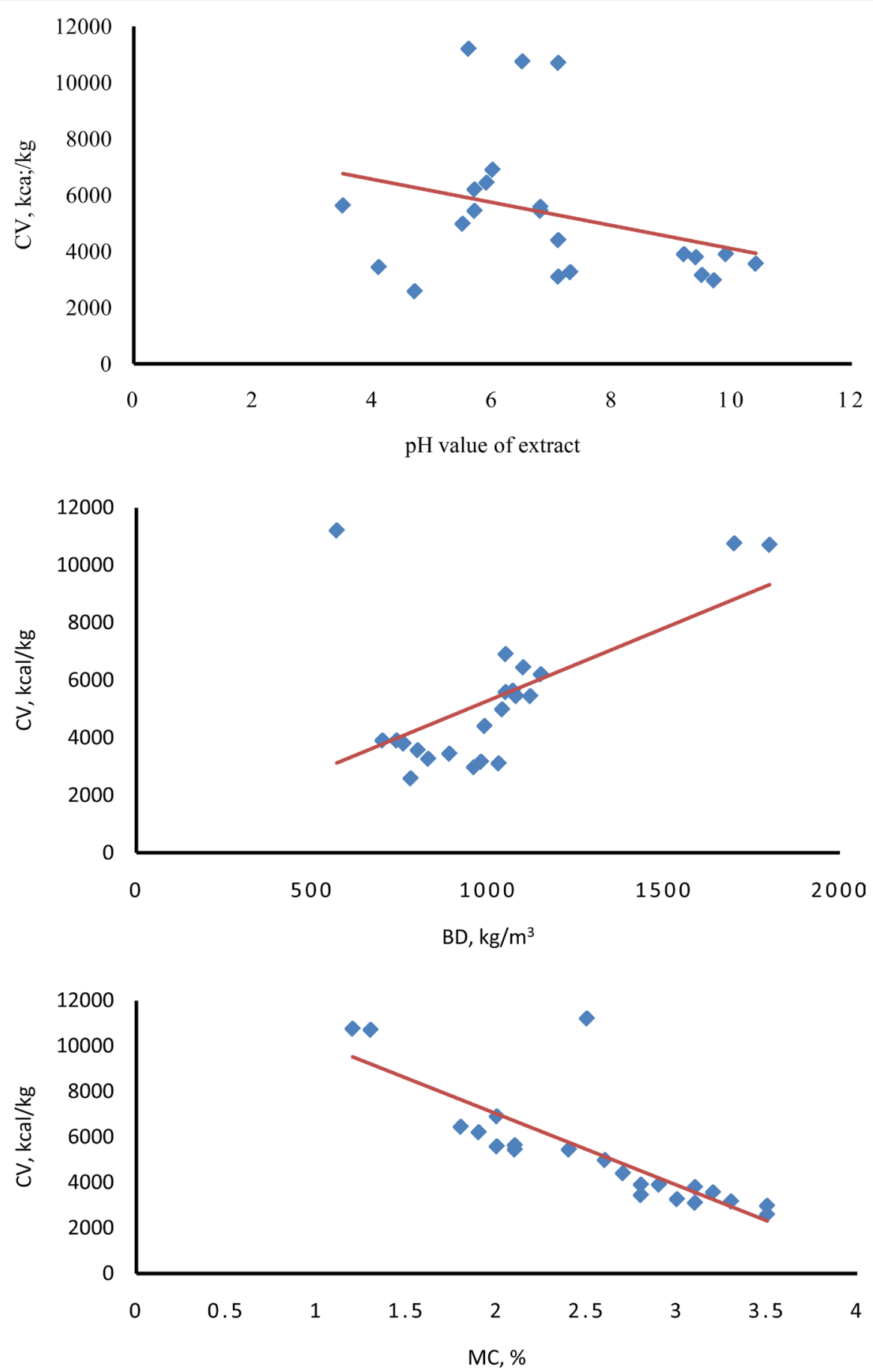

Figure 1. Correlation of calorific value of manures with proximate variables.

water, but also by volume owing to the energy required to evaporate the water. The moisture content of 22 manures was ranged from $1.2 \%-3.5 \%$ with mean value $(\mathrm{p}=0.05)$ of $2.5 \% \pm 0.3 \%$. The $\mathrm{MC}$ had good negative correlation $(\mathrm{r}=-0.81)$ with the $\mathrm{CV}$ of the material, Table 1 and Figure 1.

\subsection{Volatile Compounds, Fixed Carbon and Ash Residue of Stool}

The TG-DTG chromatogram of cattle manure (CM) was shown in Figure 2. The first stage (temperature below $150^{\circ} \mathrm{C}$ ) corresponds to the drying period where light volatiles, mainly water were liberated throughout the pro- 
cedure. Slender decay of sample weight was observed as illustrated in Figure 2. De-volatilization was the major step in all thermos chemical conversion process involving manure. This step was represented by the second stage of decomposition, occurring at temperature between $150^{\circ} \mathrm{C}$ to $400^{\circ} \mathrm{C}$, where remarkable slope of the TG curve was observed, corresponding to significant drop in weight of samples, $40.7 \%$ due to liberation of volatile organic compounds from rapid thermal decomposition of hemicelluloses, cellulose and some part of lignin. In third stage, the curve was decreased sharply up to $600^{\circ} \mathrm{C}$, may be due to decomposition of lignin materials with weight loss of $19.5 \%$. The non-volatile materials (i.e. fixed carbon and ash residue) in the biomass was found to be $\approx 30.0 \%$

The ash residue (AR) of 22 stool samples was ranged from $12 \%-31 \%$ with mean value $(p=0.05)$ of $23 \% \pm$ $2 \%$ as shown in Figure 3. The AR fraction was observed to influence inversely the heat value of the manures (Figure 3). The $\mathrm{pH}$ value of as residue extract was ranged from $3.8-11.5$ with mean value $(\mathrm{p}=0.05)$ of $8.8 \pm$ 0.9 . The ash residue of birds was found to be acidic in nature.

\subsection{Calorific Value}

The CV of 22 manure samples derived from animals and birds was measured, ranging from $2580-11,200$ $\mathrm{kcal} / \mathrm{kg}$ with mean value $(\mathrm{p}=0.05)$ of $5333 \pm 1073 \mathrm{kcal} / \mathrm{kg}$. Among them, the highest $\mathrm{CV}$ of the manures derived from the animals i.e. lion and hyena was observed, may be due to loading with energetic compounds, Table 1 . The age of cattle also influenced the $\mathrm{CV}$ of the manure, and the maximum value was marked in the middle age group as shown in human, Figure 4. The spray of additives i.e. $\mathrm{NaNO}_{3}$ and $\mathrm{Na}_{2} \mathrm{WO}_{4}(0.1 \%)$ during pellet formation was found to enhance the heat value of the manure as presented in Figure 4 . The manure samples derived from 22 different animals and birds were grouped into clusters using the proximate parameters as discriminating factors as shown in Figure 5. The manures having the $\mathrm{CV}<10,000 \mathrm{kcal} / \mathrm{kg}$ was grouped into the I-cluster. In this cluster, 19 manure samples derived from animals and birds (sample no 2 - 14 and 16 - 21) were included. In the II-cluster, the manures having CV > 10,000 kcal/kg were included.

\subsection{Comparison of Combustion Characteristics of Animal Manure, Rice Straw and Coal}

The CV of materials i.e. CM, RS and coal was found to be 3900,5600 and $9100 \mathrm{kcal} / \mathrm{kg}$, respectively. The $\mathrm{PM}_{10}$ emission fluxes $(\mathrm{n}=3)$ for RS, coal and CM was 3500,8500 and $12,200 \mathrm{mg} / \mathrm{kg}$, respectively. The highest emission fluxes of the $\mathrm{CM}$ were observed, and may be due to slow burning kinetics. The segregation of $\mathrm{PM}_{10}$

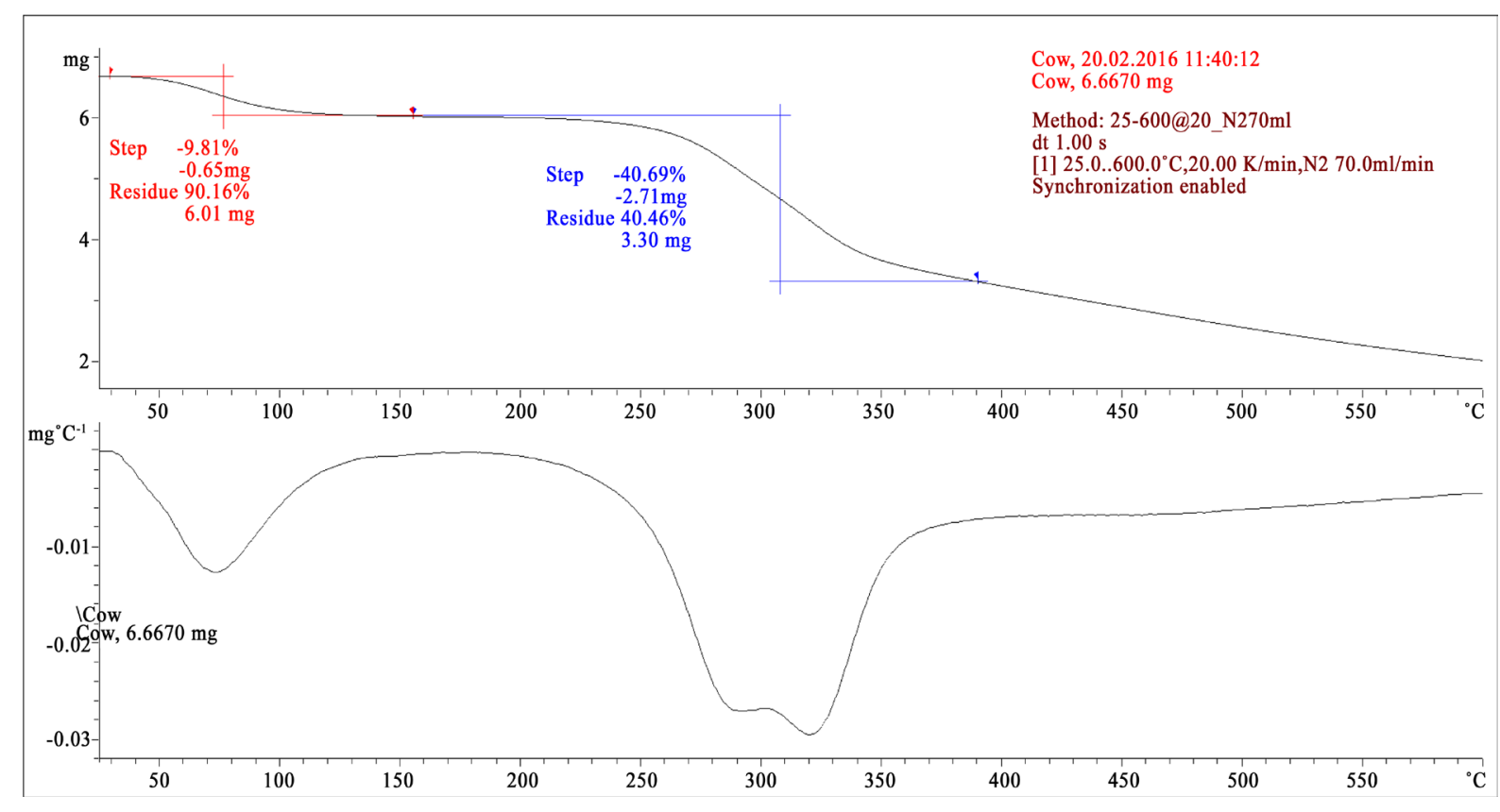

Figure 2. TG-DTG chromatogram of cattle manure. 


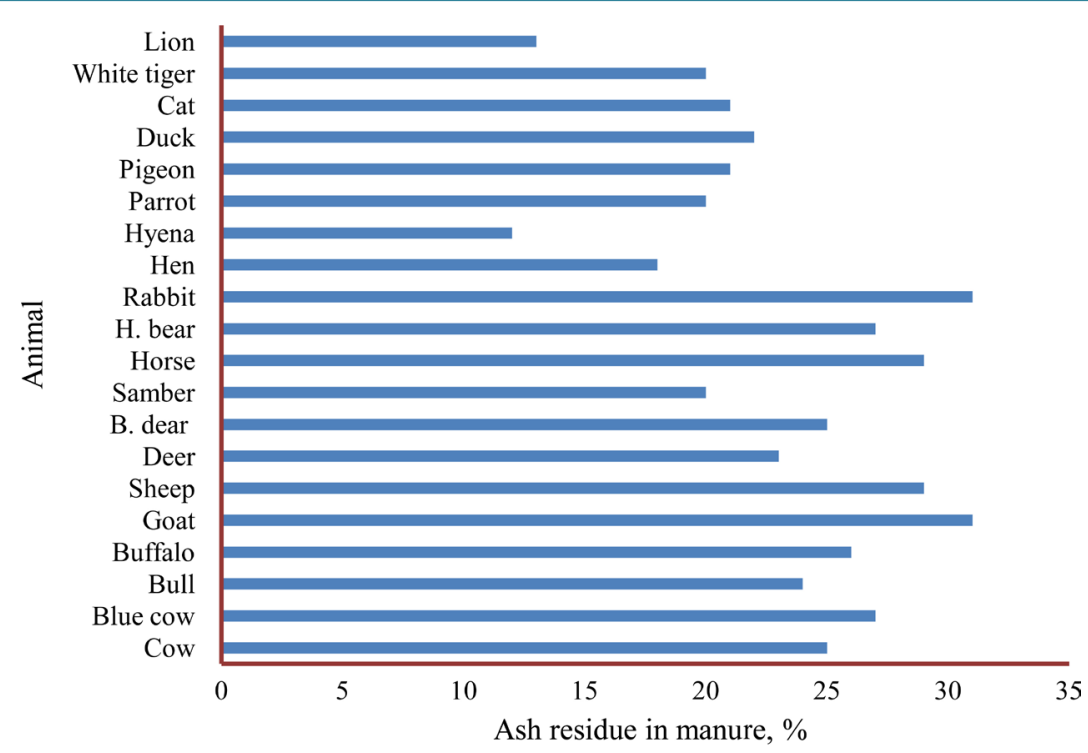

(a)

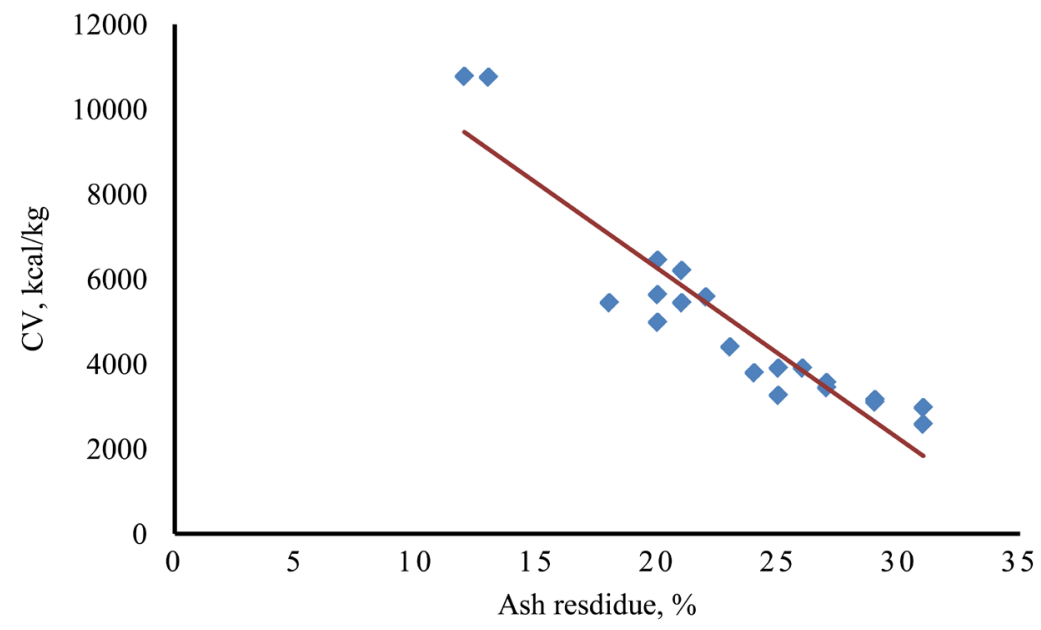

(b)

Figure 3. Ash content of manure (a) and relationship with calorific value (b).

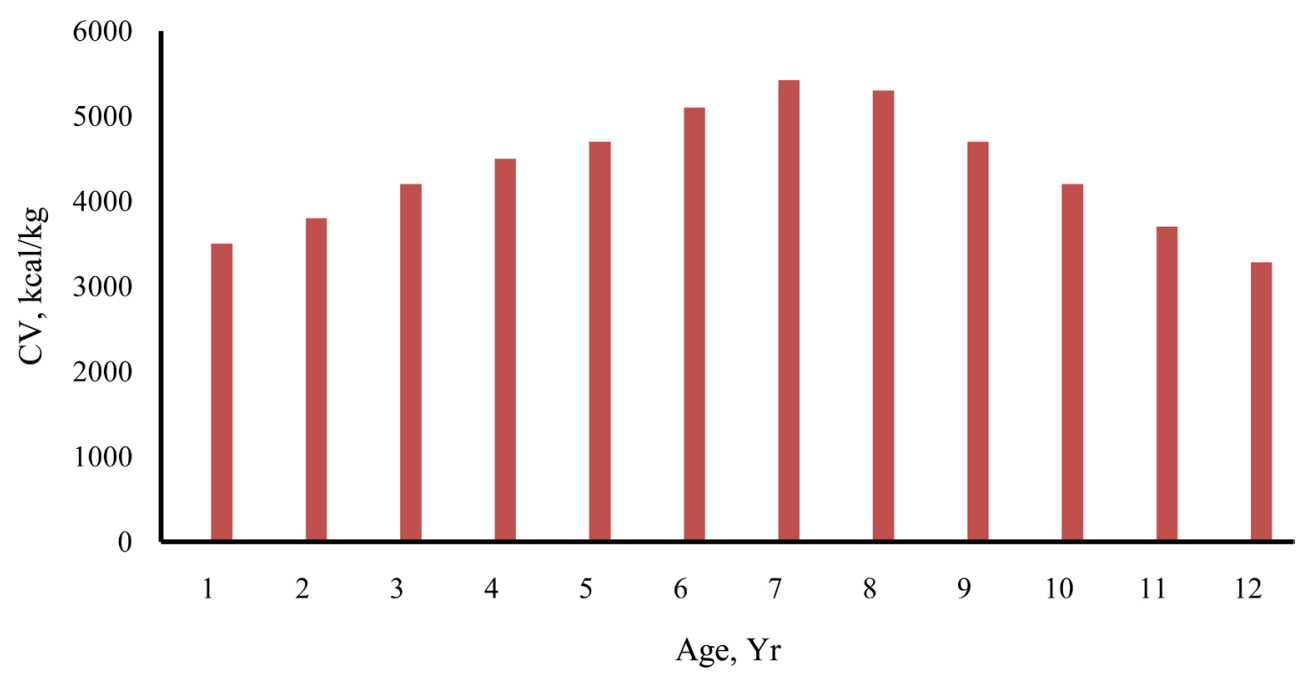




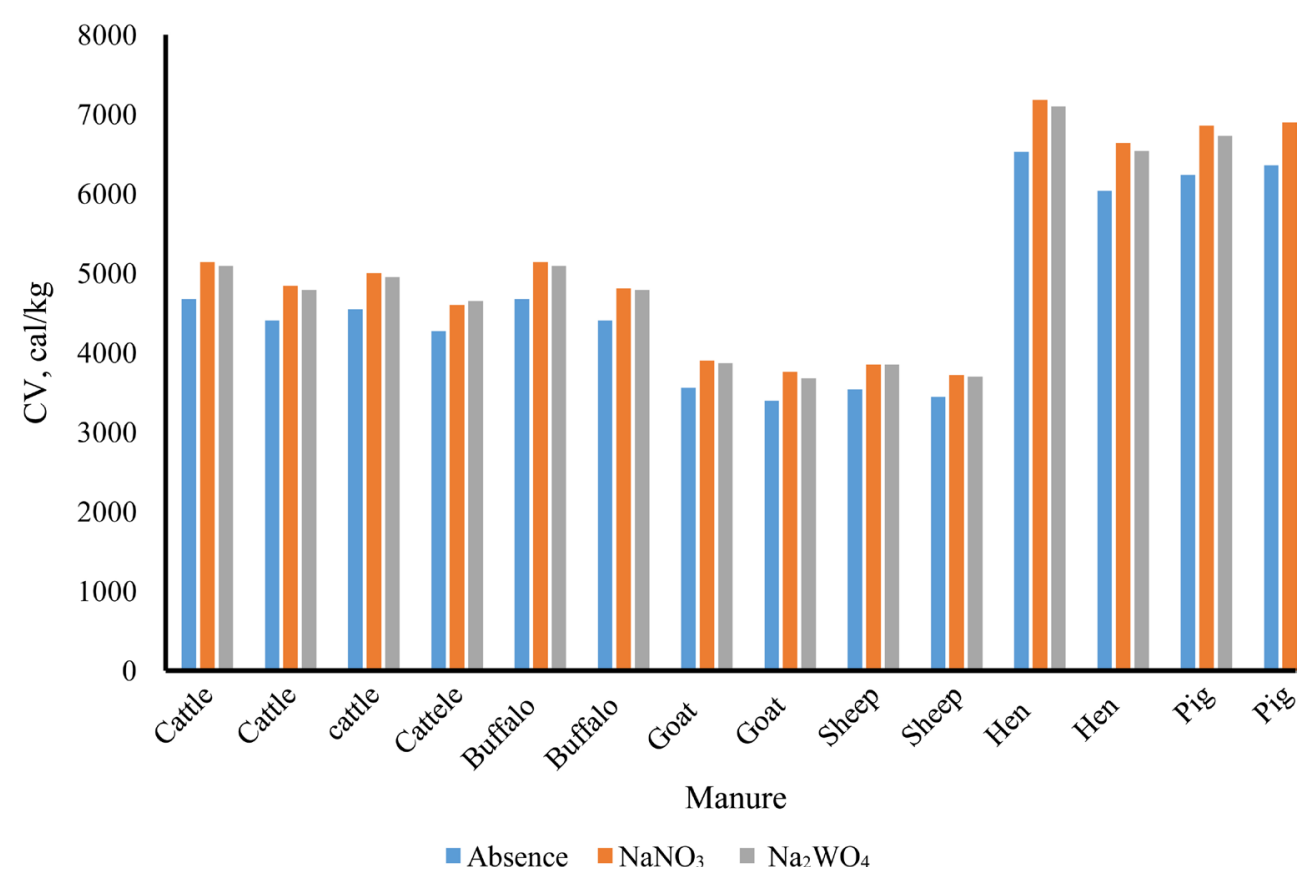

Figure 4. Effect age of cattle and additives in the calorific value of manure.

Table 2. Particulate matter characteristics, $\mathrm{g} / \mathrm{kg}$.

\begin{tabular}{|c|c|c|c|c|}
\hline S. No. & Parameter & Cattlemanure & Rice straw & Coal \\
\hline \multirow[t]{5}{*}{1} & Emission flux of $\mathrm{PM}_{10}, \mathrm{~g} / \mathrm{kg}$ & 11 & 3.6 & 8.4 \\
\hline & Relative abundance of segregated $\mathrm{PM}_{10} \%$ & & & \\
\hline & $\mathrm{PM}_{10-9.0}$ & 25 & 4 & 4 \\
\hline & $\mathrm{PM}_{9.0-5.8}$ & 16 & 3 & 5 \\
\hline & $\mathrm{PM}_{5.8-4.7}$ & 9 & 3 & 3 \\
\hline \multirow[t]{5}{*}{2} & $\mathrm{PM}_{4.7-3.3}$ & 6 & 2 & 7 \\
\hline & $\mathrm{PM}_{3.3-2.1}$ & 12 & 7 & 14 \\
\hline & $\mathrm{PM}_{2,1-1,1}$ & 10 & 14 & 13 \\
\hline & $\mathrm{PM}_{1.1-0.7}$ & 12 & 20 & 17 \\
\hline & $\mathrm{PM}_{0.7-0.0}$ & 10 & 47 & 37 \\
\hline 3 & $\mathrm{EC}, \%$ & 10 & 13 & 14 \\
\hline 4 & $\mathrm{OC}, \%$ & 44 & 55 & 42 \\
\hline 5 & $\mathrm{Cl}^{-}$ & 2.2 & 0.24 & 1.4 \\
\hline 6 & $\mathrm{SO}_{4}^{2-}$ & 0.61 & 0.11 & 0.76 \\
\hline 7 & $\mathrm{Na}$ & 0.54 & 0.06 & 0.23 \\
\hline 8 & $\mathrm{~K}$ & 1.1 & 0.4 & 0.7 \\
\hline 9 & $\mathrm{Mg}$ & 0.04 & 0.21 & 0.05 \\
\hline 10 & $\mathrm{Ca}$ & 0.23 & 0.16 & 0.14 \\
\hline
\end{tabular}

of the CM, RS and coal into 8 modes i.e. $\mathrm{PM}_{10.0-9.0}, \mathrm{PM}_{9.0-5.8}, \mathrm{PM}_{5.8-4.7}, \mathrm{PM}_{4.7-3.3}, \mathrm{PM}_{3.3-2.1}, \mathrm{PM}_{2.1-1.1}, \mathrm{PM}_{1.1-0.7}$ and $\mathrm{PM}_{0.7-0.0} \mu \mathrm{m}$ is shown in Table 2 and Figure 6. The highest concentration of the coarse particulates, $\mathrm{PM}_{10.0-9.0}$ was observed in the CM particulates unlikely to the RS and coal. The RS and coal particulates were dominated by the ultra-fine and nano particulates. The carbons contributed the major fraction of the PM emitted during the burning processes. The EC concentration in the PM of CM, RS and coal was found to be comparable, $10 \%$ $14 \%$. Relatively higher OC fraction in the $\mathrm{PM}_{\mathrm{RS}}$ was marked, may be due to evaporation of the VOCs. Higher 
concentration of $\mathrm{Cl}^{-}, \mathrm{Na}^{+}$and $\mathrm{K}^{+}$were found to be enriched in the $\mathrm{PM}_{\mathrm{CM}}$.

The characteristic of ash residue (AR) of cattle manure, rice straw and coal is summarized in Table 3 . Remarkably high fractions of ash residue (AR) in the cattle manure were observed, Table 3 . The $\mathrm{pH}$ value of $\mathrm{CM}$ and RS was found to be of alkaline nature unlikely to the coal ash, Table 3. Relatively higher concentration of

Table 3. Ash residue characteristics, $\%$.

\begin{tabular}{ccccc}
\hline S. No. & Parameter & Cattle dung & Rice straw & Coal \\
\hline 1 & Ash content & 25 & 7.2 & 8.1 \\
2 & Color & White & White & White \\
3 & $\mathrm{pH}$ value & & 6.2 & 9.2 \\
4 & $\mathrm{EC}, \%$ & 5.1 & 8.3 & 0.7 \\
5 & $\mathrm{OC}, \%$ & 0.3 & 0.5 \\
6 & $\mathrm{Cl}^{-}$ & 1.4 & 6.8 & 1.9 \\
7 & $\mathrm{SO}_{4}^{2-}$ & 2.5 & 0.7 & 0.1 \\
8 & $\mathrm{Na}$ & 0.3 & 0.2 & 0.4 \\
9 & $\mathrm{~K}$ & 4.5 & 6.1 & 2.1 \\
11 & $\mathrm{Mg}$ & 1.2 & 4.4 & 0.4 \\
\hline
\end{tabular}

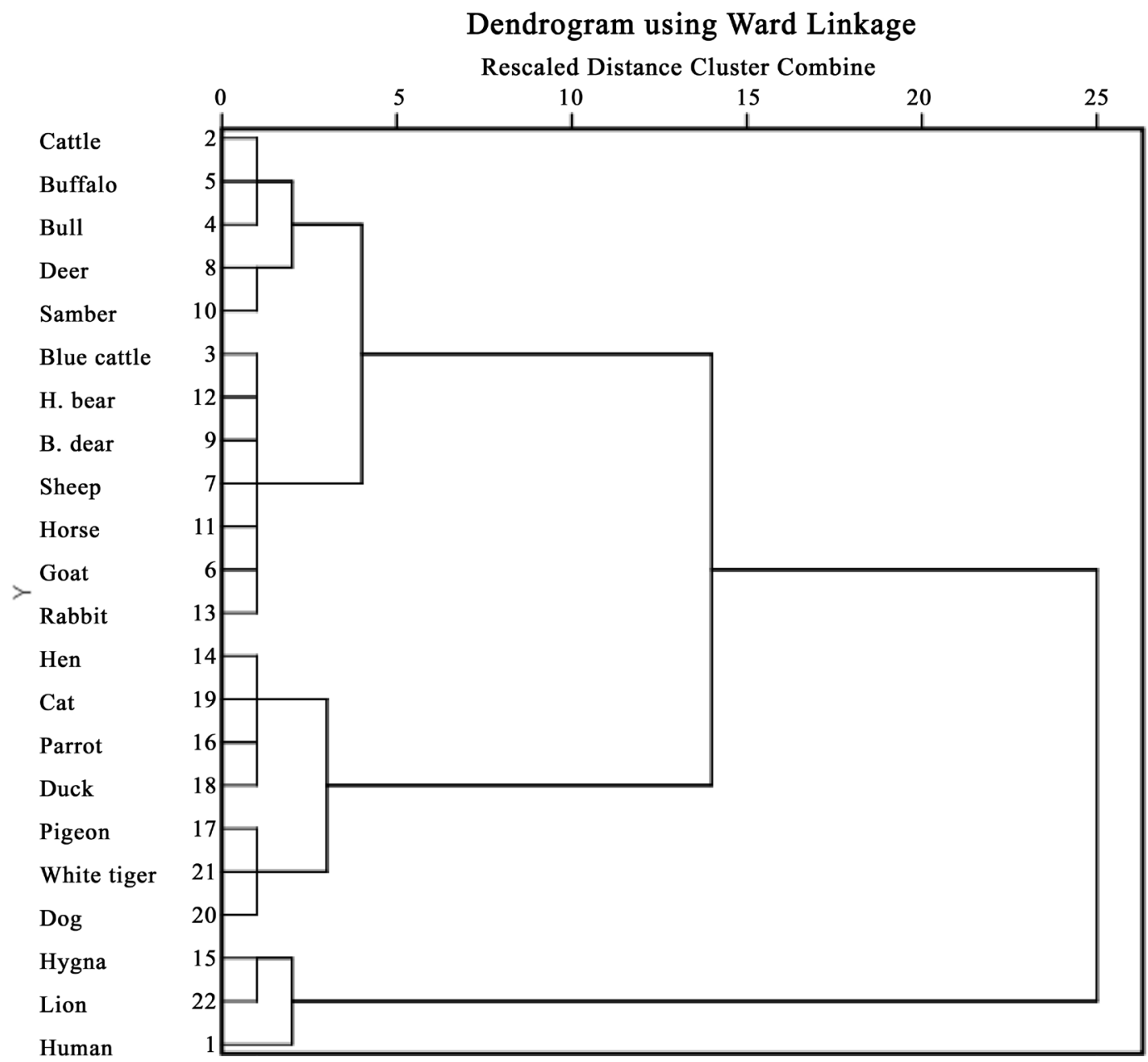

Figure 5. Dendogram for CV of animal manures. 


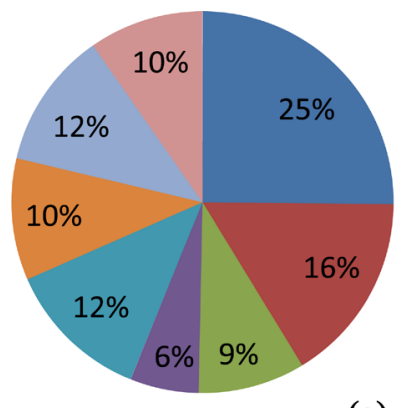

- PM10-9.0

— PM 9.0-5.8

므 PM 5.8-4.7

- PM 4.7-3.3

ㅁ PM 3.3-2.1

口 PM 2.1-1.1

ㅁ. PM 1.1-0.7

(a)

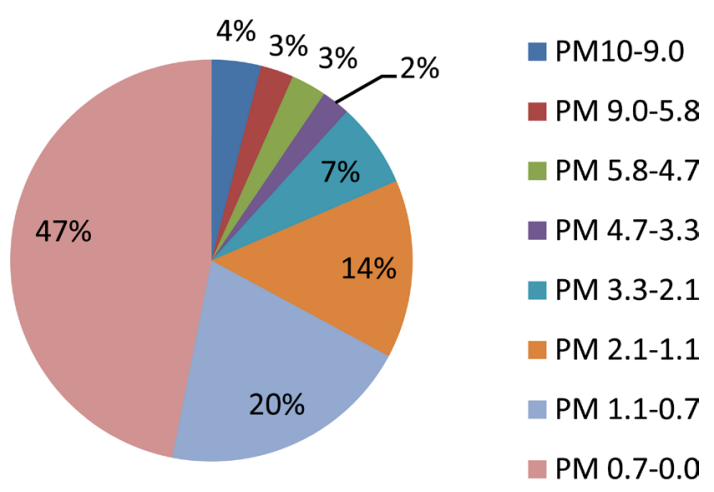

(b)

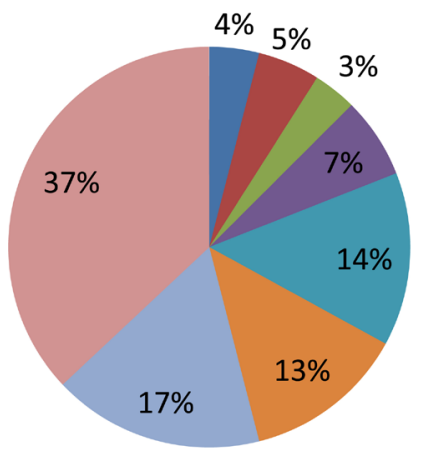

(c)
- PM10-9.0

- PM 9.0-5.8

- PM 5.8-4.7

口 PM 4.7-3.3

- PM 3.3-2.1

口 PM 2.1-1.1

- PM 1.1-0.7

PM 0.7-0.0

Figure 6. Segregation diagram for cattle (a), rice straw (b) and coal (c) particulate matters.

EC in the all ash residue was marked. The OC content in the all AR was found to be reduced remarkably as compared to the respective PM. However, the higher concentration of ions was observed to be present in the CM than the RS and coal ash residue.

\section{Conclusion}

Of course, the calorific value of coal was found to be higher than the animal manure and RS. The lowest emission fluxes of PM were seen in the manure combustion. The AR of CM was found to be loaded with higher fraction of nutrients. The coal ash residue was observed to be acidic due to higher fraction of sulfuric acid. The animal manures are major sources of microbes, and their sustainable utilization may reduce the prevalence of occurring of air and water borne diseases in the ecosystem.

\section{Acknowledgements}

We are thankful to the Pt. Ravishankar Shukla University, Raipur for providing the teaching assistantship to the 
PKS and SC.

\section{References}

[1] Abelha, P., Gulyurtlu, I., Boavida, D., Seabrros Barros, J., Cabrita, I., Leahy, J., Kelleher, B. and Leahy, M. (2003) Combustion of Poultry Litter in a Fluidised Bed Combustor. Fuel, 82, 687-692. http://dx.doi:org/10.1016/S0016-2361(02)00317-4

[2] Echiegu, E.A, Nwoke, O.A., Ugwuishiwu, B.O. and Opara, I.N. (2013) Calorific Value of Manure from Some Nigerian Livestock and Poultry as Affected by Age. International Journal of Scientific \& Engineering Research, 4, 9991004.

[3] Ro, K.S., Cantrell, K.B., Hunt, P.G., Ducey, T.F., Vanotti, M.B. and Szogi, A.A. (2009) Thermochemical Conversion of Livestock Wastes: Carbonization of Swine Solids. Bioresource Technology, 100, 5466-5471. http://dx.doiorg/10.1016/j.biortech.2009.03.005

[4] Garcia, R., Pizarro, C., Lavin, A.G. and Bueno, J.L. (2014) Spanish Biofuels Heating Value Estimation. Part I: Ultimate Analysis Data. Fuel, Part-B, 117, 1130-1138. http://dx.doiorg/10.1016/j.fuel.2013.08.048

[5] Kosov, V.F., Kuzmina, J.S. and Sytchev, G.A. (2013) Thermotechnical Characteristics of Granulated Fuel Made of Chicken Litter: Researching and Ways of Its Upgrading. The 28th International Conference on Interaction of Intense Energy Fluxes with Matter, Elbrus, Kabardino-Balkaria, Russia, 57.

[6] Quiroga, G., Castrillón, L., Fernández-Nava, Y. and Marañón, E. (2010) Physico-Chemical Analysis and Calorific Values of Poultry Manure. Waste Management, 30, 880-884. http://dx.doiorg/10.1016/j.wasman.2009.12.016

[7] Lundgren, J. and Pettersson, E. (2009) Combustion of Horse Manure for Heat Production. Bioresource Technology, 100, 3121-3126. http://dx.doi.org/10.1016/j.biortech.2009.01.050

[8] Marculescu, C., Ionescu, G., Ciuta, S. and Stan, C. (2013) Energetic Analysis of Meat Processing Industry Waste. UPB Scientific Bulletin, Series C, 75, 291-300.

[9] Recebli, Z., Selimli, S., Ozkaymak, M. and Gonc, O. (2015) Biogas Production from Animal Manure. Journal of Engineering Science and Technology, 10, 722-729.

[10] Kuleape, R., Cobbina, S.J., Dampare, S.B., Duwiejuah, A.B., Amoako, E.E. and Asare, W. (2014) Assessment of the Energy Recovery Potentials of Solid Waste Generated in Akosombo, Ghana. African Journal of Environmental Science and Technology, 8, 297-305. http://dx.doi.org/10.5897/AJEST2014.1663

[11] ASTM International (2008) ASTM Standard D2395-2007a: Standard Test Methods for Specific Gravity of Wood and Wood-Based Materials. ASTM International, West Conshohocken.

[12] ASTM International (2008) ASTM D1102-84, Test Method for Ash in Wood. Annual Book of ASTM Standards, 153154.

[13] ASTM D5865-13 (2013) Standard Test Method for Gross Calorific Value of Coal and Coke. ASTM International, West Conshohocken. www.astm.org

[14] IBM SPSS Statistics 23 (2015) http://www-01.ibm.com/support/docview.wss?uid=swg21698495 